Turkish Online Journal of Qualitative Inquiry (TOJQI)

Volume 11, Issue 2, April 2020: 218-246

DOI: $10.17569 /$ tojqi.611707

Research Article

\title{
Investigating the Factors Affecting Students' Satisfaction in a Programming Course Designed in 3D Virtual Worlds ${ }^{12}$
}

\author{
Ali Battal ${ }^{3}$ and S. Tuğba Tokel ${ }^{4}$
}

\begin{abstract}
The main purpose of this study is to understand the satisfaction level of students to teach the basics of programming in 3D virtual worlds and investigate the factors affecting their satisfaction. Multiple case study with three cases were conducted in three different educational programs: as curricular (Case-1), extra-curricular (Case-2) and after-school (Case-3). Satisfaction scale adopted from previous study was used to understand current level of satisfaction and semi-structured interviews were conducted with participants to reveal factors affecting satisfaction. Descriptive analysis of quantitative data showed that that the most satisfied students were those from Case- $1(\mathrm{M}=4.35)$, Case- $3(\mathrm{M}=4.28)$ and Case- 2 $(M=3.99)$, respectively. Single case analysis of qualitative data revealed the factors increasing and decreasing satisfaction of the students. Apart from the story about the tasks, group study, object construction, having tasks, off-task activities, 3D environment and tour in the environment emerged as an increasing factor across all three cases at different ratios. Technical problems, studying alone, difficulty of the tasks, and avatar-related problems were the factors stated by some of the students across all cases as decreasing factors. Cross-case analysis provided a table which shows the similarities and differences among the cases.
\end{abstract}

Keywords: $3 D$ Virtual Worlds, factors affecting satisfaction, satisfaction, programming for children

\footnotetext{
${ }^{1}$ This article is a part of the doctoral dissertation of the first researcher and it was presented at the 6th International Instructional Technologies and Teacher Education Symposium (ITTES-2018).

2 Applied Ethics Research Center of the university granted permission to conduct this study with a document number "28620816/341" on 09.09.2015.

${ }^{3}$ Asst.Prof.Dr., Selçuk University, Faculty of Education, Department of Educational Sciences, albatt@gmail.com, https://orcid.org/0000-0001-8659-2294

${ }^{4}$ Assoc.Prof.Dr., Middle East Technical University, Faculty of Education, Department of Computer Education \& Instructional Technology, stugba@metu.edu.tr, https://orcid.org/0000-0002-2855-6452

Received: 27.08.2019, Accepted: 29.04.2020
} 


\title{
3B Sanal Dünyalarda Tasarlanan Bir Programlama Dersinde Öğrencilerin Memnuniyetine Etki Eden Faktörlerin İncelenmesi
}

\begin{abstract}
Öz
$\mathrm{Bu}$ çalışmanın amacı 3B sanal dünyalarda programlamanın temellerini öğretmeyi amaçlayan bir derste öğrencilerin memnuniyet seviyelerini ortaya çıkarmak ve öğrencilerin memnuniyetine etki eden faktörleri belirlemektir. Bu amaçla araştırma yöntemi olarak üç farklı eğitim programında uygulanmış çoklu durum çalışması seçilmiştir. Bu durum çalışmaları sırasıyla müfredata entegre (Durum 1), müfredat dışı (Durum 2) ve okul sonrası (Durum 3) şeklinde eğitim programlarında uygulanmıştır. Alanyazındaki çalışmalardan faydalanılarak uyarlanan memnuniyet ölçeği ile öğrencilerin memnuniyet düzeyi ölçülerken, öğrenci ve öğretmenler ile yapılan yarı yapılandırılmış görüşmeler ile memnuniyete etki eden faktörler ortaya çıkarılmıştır. Nicel verilerin analizinde betimsel analiz yöntemleri kullanılmış olup Durum $1(\mathrm{M}=4.35)$, Durum-3 $(\mathrm{M}=4.28)$ ve Durum-2'nin $(\mathrm{M}=3.99)$ öğrencileri sirasiyla, bu ortamlarda verilen programlama dersinden en çok memnun olan öğrenciler olarak belirlenmiştir. Nitel verilerin tekli durum analizi sonuçları memnuniyeti artıran ve azaltan faktörleri ortaya çıkarmıştır. Görevlerin hikayesi dışında, grup çalışması, obje oluşturma, görevlerin olması, görev dışı aktiviteler, 3B ortam ve ortamda gezinme her üç durum çalışmasında da değişken oranlarda memnuniyeti artıran faktörler olarak bulunmuştur. Teknik problemler, yalnız çalışma, görevlerin zorluğu ve avatar ile ilgili problemler her üç durum çalışmasının öğrencileri tarafından memnuniyeti azaltan faktörler olarak ortaya çıkmıştır. Durumlar arası analiz sonuçları ise her üç durum çalışması sonuçlarının benzerlik ve farklılıklarını belirten bir tablo ile sunulmuştur.
\end{abstract}

Anahtar kelimeler: 3B sanal dünyalar, memnuniyeti etkileyen faktörler, memnuniyet, çocuklar için programlama 


\section{Introduction}

Programming is a well-known term nowadays which is considered as essential for anyone at any age from primary school up to university level (Sauppé, Szafir, Huang, \& Mutlu, 2015). Therefore, many countries and schools have been trying to introduce concepts related to programming to children in different ways (Kafai \& Burke, 2014). There are numerous efforts to integrate programming into school curriculum by updating current courses as well as developing new standalone courses such as "Computer Science." Extra-curricular activities have been trying to be implemented into school settings such as establishing programs for software and game design projects. Such kinds of program are important since they are good examples of how programming could be contextualized in a program independently of curriculum. Besides, after-school programs out of school settings are offered to introduce learners to programming in different contexts.

Learning programming is generally considered difficult by learners of any age (Guzdial, 2004). Therefore, there is a need to use tools or environments as an aid to making programming easier to grasp (Gomes \& Mendes, 2007). In their study, Kelleher and Pausch (2005) reviewed nearly 80 tools and categorized them according to their mechanical and motivational process benefits. Tools in the mechanical process category focused on making the mechanics of programming more manageable such as removing unnecessary syntax, designing languages closer to spoken language, introducing programming in visible context, and finding alternatives to typing programs. These kinds of tools allow learners to focus on the logic and underlying structures of programming rather than becoming overwhelmed with all the other issues associated with programming. Tools in the motivational process category were aimed at increasing learners' motivation during learning by offering a social and motivating context through designing activities that draw learners' attention such as moving cars, or the construction of objects. These kinds of tools are also important since programming is considered a solitary activity (Brennan, 2013; Rosenbaum, 2008).

VWs offers different types of opportunities to educators such as immersive 3D environment, avatars and multiple users, and multiple communication forms (Dickey, 2005a, 2005b); interaction with objects and other avatars (Hew \& Cheung, 2010); persistence of objects, 
immersive environment through the use of realistic 3D graphics (Dalgarno \& Lee, 2010; Delwiche, 2006; Dieterle \& Clarke, 2006); and object construction and manipulation (Dawley $\&$ Dede, 2014; Messinger et al., 2009).They allow educators to incorporate a large variety of learning options and strategies into their teaching. Dreher, Reiners, Dreher and Dreher (2009) advocated the use of virtual worlds in learning programming since they would allow direct visualization of the outcome, which could be seen animated virtually, and would provide learners with quick and concrete feedback. In addition, learners are able to test their code by applying it in a certain context and social environment. It is also possible to study in groups thanks to the multiuser capability of VWs, which might promote group or pair programming (Beck, 2000). Teaching programming in virtual worlds could motivate learners intrinsically and offer them a range of benefits when compared to teaching with traditional methods. Virtual worlds with their various features could be used as a tool in the teaching of programming. They offer exciting new environment for learners to engage in programming through the construction of meaningful 3D artefacts within group studies; something that is arguably difficult to achieve with other programming environments (Pellas \& Vosinakis, 2017).

The use of VW with its features has a positive effect on students' satisfaction in general (Hew \& Cheung, 2010), and in programming education (Buffum et al., 2015; Girvan, Tangney, Savage, 2013; Hulsey, Pence, Hodges, 2014). Hulsey et al. (2014) organized a weeklong camp named "Camp CyberGirls" in order to introduce the basic concepts of programming to 16 female high school students. In doing so, they prepared a virtual environment consisting of 10 tasks including modeling and scripting activities; for example, modeling and scripting a sliding door. Modeling and scripting were performed using the environment's functions such as writing scripts in LSL. Results of the study indicated that although it was more complicated for students to complete tasks compared to other programming tools such as Alice or Scratch, students had the chance to perform a wide variety of learning activities. Moreover, studying and completing tasks in VW was a source of motivation for the students and they realized a high degree of satisfaction. In another study by Girvan, Tangney, and Savage (2013), an exploratory case study was conducted with 24 graduate students with little or no programming experience. The participants studied in pairs for a period of four weeks and constructed interactive objects such as a playable piano. The study's results showed that students gained a high sense of satisfaction with the use of VW since studying in VW was funny and helpful in engaging them with the learning objectives. Enabling group study is one of the characteristics of VWs since they allow learners to perform tasks together rather than just communicate (Dalgarno \& Lee, 2010; 
Duncan, Miller, \& Jiang, 2012). There is evidence in the literature that shows group study has a positive effect on students' learning and satisfaction (Sajjanhar \& Faulkner, 2014), engagement to perform activities (Pellas \& Peroutseas, 2016), and enjoyment (Buffum et al., 2015 ) in programming education. Rosenbaum (2008) argued in his study that the ease of being able to create scripts in LSL by using a Scratch-like tool, Scracth for Second Life (S4SL) made the students satisfied.

Previous studies used VWs in teaching programming to students from high schools though to postgraduate by using Linden Scripting Language (LSL), the language of VWs (e.g., Girvan et al., 2013; Hulsey, Pence, \& Hodges, 2014; Pellas, 2014; Seng \& Edirisinghe, 2007). However, studies concerned with the use of VWs in teaching programming have been limited and scarce for children. Besides, studies examining its use in different educational programs and comparing and contrasting the results have not been found in the literature; therefore, there is a need to understand the use of virtual worlds in teaching the basics of programming to children through different educational programs. The aim of this study is to address the satisfaction of participants and to reveal factors affecting satisfaction across the different educational programs.

The research questions of this study are as follows:

- How the students' satisfaction who were taught programming via VWs in different contexts changed?

- What factors affected their satisfaction?

\section{Method}

Multiple case study research was conducted due to various reasons. Firstly, too little information about the use of virtual worlds in programming education for children was known, and therefore it needs to be explored in a more detailed way. Secondly, case study provides much detailed information about the phenomenon being studied in its context and offers a more complete picture of what happened and why (Neale, Thapa, \& Boyce, 2006). Merriam (2009) added that case study is useful when studying educational innovations. Lastly, it is possible to show different perspectives on the phenomenon by analyzing multiple cases (Creswell, 2007). 


\subsection{Selection of Cases and Participants}

Two levels of sampling are followed in multiple case studies (Merriam, 1998), with cases selected in the first level and participants selected for each case in the second level. Purposeful sampling is used when the researcher "wants to discover, understand and gain insight and therefore must select a sample from which the most can be learned" (Merriam, 1998, p. 61) and when the researcher wants to reach information-rich cases (Patton, 1990). At this point, the researcher selects the most appropriate cases which provide the most available data (Stake, 2005). Building a rationale or criteria for purposeful sampling strategy is the next step (Creswell, 2007; Merriam, 1998; Stake, 2005; Yin, 2003). In the current study, the primary criteria was to understand the use of virtual worlds in programming education offered to children in different settings. Previous studies showed that introductory level programming education for children has been offered (Kafai \& Burke, 2014) in three educational programs; curricular, extra-curricular and after-school programs. Therefore, the cases selected for the current study were based on these three educational program types: curricular, extra-curricular and after-school programs.

The first case was a curricular program in which programming education was adopted from the current curriculum of an existing ICT course in a school setting. This case took place in a private school located in Ankara. The implementation phase for this case lasted for a period of eight weeks during the spring semester of the 2015-2016 academic year. The first part of the study (activities on the first island) was conducted in the school's laboratory, whilst the second part (activities on the second island) was conducted in the CEIT laboratory at the researcher's university due to technical issues. The second case was an extra-curricular program held in club, named "Game Programming", of a private school located in Ankara. Attending the club was optional and only students from the $5^{\text {th }}$ and $6^{\text {th }}$ grades participated in the club voluntarily. Club participants met for one and half lesson hours per week throughout the semester. Implementation in this case lasted for 10 weeks during the spring semester of the 2015-2016 academic year. The third case was an after-school program held in an informal learning environment occurring outside of the school. This case was conducted on a course offered at the Continuing Education Center of a public university. The course lasted for a period of five weeks during May and June of 2016, with one class lasting three lesson hours per week. 
Table 1

Characteristics of participants

\begin{tabular}{|c|c|c|c|c|c|c|}
\hline & \multicolumn{2}{|c|}{ Curricular } & \multicolumn{2}{|c|}{ Extra-Curricular } & \multicolumn{2}{|c|}{ After-School } \\
\hline & $n$ & $\%$ & $n$ & $\%$ & $n$ & $\%$ \\
\hline \multicolumn{7}{|c|}{ Gender } \\
\hline Female & 6 & 50.00 & 2 & 10.00 & 2 & 25.00 \\
\hline Male & 6 & 50.00 & 18 & 90.00 & 6 & 75.00 \\
\hline \multicolumn{7}{|c|}{ Age } \\
\hline 10 & 3 & 25.00 & 1 & 5.00 & 2 & 25.00 \\
\hline 11 & 8 & 66.7 & 15 & 75.00 & 4 & 50.00 \\
\hline 12 & 1 & 8.30 & 3 & 15.00 & 2 & 25.00 \\
\hline 13 & - & - & 1 & 5.00 & - & \\
\hline Mean & 10.83 & & 11.20 & & 11.00 & \\
\hline
\end{tabular}

The number of students in Case-1 were 12, consisting of six females and six males. In Case-2, there were two female and 18 male students with a total of 20 . The number of students in Case3 is eight, consisting of two females and six males. Students in Case- 1 were between the ages of 10 and 12 years, with a mean age of 10.83 years. Participants of Case- 2 were also aged between 10 and 13 with a mean age of 11.2 years. Participants of Case- 3 were aged between 10 and 12 years, with mean age of 11 years.

\subsection{Data Collection Methods}

In qualitative studies, data are collected from participants via different forms (Creswell, 2012; Merriam, 1998; Stake, 2006; Yin, 2003). Creswell (2012) defined different kinds of data forms as observations, interviews, documents, audiovisual materials and so on. Yin (2003) also proposed six different types of data forms; documents, archival records, interviews, direct observations, participant-observations, and physical artifacts. Two data collection forms were used in the current study: semi-structured interviews, and two questionnaires. Semi-structured interviews were conducted with the participant students as well as the teachers. Two separate semi-structured interview forms were developed after examining the related literature. In order to finalize the interview forms, a three-step method was employed. Firstly, the interview forms were applied as part of the pilot study. Pilot study was conducted within a voluntary organization with a group of students aged between 10 to 13 years. Some enhancements were applied to the 3D environment and the interview forms after the pilot study. Some questions were consequently revised in terms of their comprehensively and some questions were also 
added to the forms. In a second step, the interview forms were examined by five experts in terms of language, clarity, potential for misunderstandings or ambiguities. The experts consisted of one faculty member and three PhD students at CEIT, in addition to one teacher of Turkish language. Based on the experts' feedback, some questions were enhanced and refined with respect to their clarity and grammar. In the final step, the "think aloud" method was conducted with a student who was not a participant of the main study, but had a similar background to the participants. The final version interview forms were then formed following completion of the review processes mentioned.

Two questionnaire forms are also used to gather information from participants. One is for demographic information, and the other is for satisfaction levels. Merriam (1998) placed questionnaires into documents as a data collection form and defined these kinds of forms as "researcher generated documents." She defined questionnaires as "documents prepared by the researcher ... [in order] to learn more about the situation, person, or event being investigated" (Merriam, 1998, p. 119). Quantitative data collected by way of questionnaires can be used to support qualitative data collected through interviews (Merriam, 2009). Contrary to common belief, quantitative data can also be collected and integrated within case studies (Merriam, 2009; Woodside, 2010; Yin, 1981) in order to increase the credibility of the findings by employing multiple data sources. Therefore, questionnaires were used as a data collection form in the current study. Two questionnaires were employed in the study; the first being a demographic questionnaire, which was developed by the researcher based on the purpose of study. The second questionnaire consisted of a scale adopted from Chou and Liu (2005). This scale consisted of four Likert-type items ranging from (1) completely disagree to (5) completely disagree. It is used for measuring the satisfaction level of students about programming education in a virtual world. The adopted scale was written in English, and translated into Turkish by the researcher and an expert with prior translation experience. After the translation, draft versions of the questionnaires were sent to a Turkish teacher to check for clarity, grammatical errors, and for the appropriateness of the language used considering the age group of the current study's participants. Final versions of the questionnaires were achieved after revising the draft based on the feedback received. The necessary permissions were granted before starting to collect data from the participants. The research proposal and data collection instruments were submitted to the Institutional Review Board (IRB) of the university. The METU Ethics Committee examined the documents and sanctioned the study with a document number “28620816/341” on 09.09.2015. 


\subsection{Data Analysis}

The analysis of qualitative data is the process of transforming data into meaningful explanations (Creswell, 2012; Merriam, 1998). Although scholars have provided many different descriptions and used many different terms for the processes of data analysis in their studies, the general process consists of three steps (Creswell, 2007). The first step includes the preparation and organization of data to be analyzed. In the second step, the data is reduced and condensed into themes and sub-themes by means of a special process called "coding." In the final step, the themes and sub-themes that emerged are presented through figures, tables and narrative text. Creswell (2012) extended these processes into six steps, which were followed during the analysis phase of this current study. In the first step, data collected through the forms were prepared for analysis. All the interviews records were transcribed verbatim. Then, all the information must be organized in a way so that it is easily accessible and "retrievable" (Merriam, 1998, p. 194). In the current study, a Computer Assisted Qualitative Data Analysis Software (CAQDAS) was utilized to analyze the qualitative data. As the next step, the coding processes was applied. Miles, Huberman, and Saldana, (2014) described code as labels assigned to a segment of information. Those labels are then used to categorize similar segments of information. At this point, the researcher needs to use an effective coding strategy that is appropriate to the data (Yıldırım \& Şimşek, 2013) and to develop meaningful and manageable coding schema (Patton, 2002). In order to achieve these, data were read several times by the researcher and then in doing so, the code emerged and evolved throughout the analysis. After the data were reduced into a code list, the themes and sub-themes were created based on the similarity of code aggregating in parallel with the research question of the study. Analysis of each single case (within-case analysis) were finalized by the steps previously mentioned. For detecting the reliability of the study, intercoder agreement strategy was applied. Descriptive statistics was used for the quantitative data obtained from the satisfaction scale. Scores obtained from the scales were presented descriptively, with no statistical analysis applied.

Cross-case analysis is another type of analysis that starts right after the completion of withincase analysis (Merriam, 1998). While within-case analysis enables the researcher to understand and explain each case separately (Miles et al., 2014), cross-cross analysis enables the researcher to spot similarities and differences across the cases (Stake, 2005). After the analysis of each single case was completed, cross-case analysis was applied in order to compare and contrast 
the emerging themes and sub-themes across the cases. Yin (2003) suggested using a table in order to present data from each case in a separate column in order to best exhibit the researcher's understanding of what differences and similarities were seen among the cases. Therefore, in the next section the findings revealed at the end of each within-case analysis are reported, and then findings of the cross-case analysis present the overall findings in tabular format, consecutively. Lastly, issues related to the credibility of the findings are addressed in the final part of this section to follow the last step of Creswell (2012).

Various strategies, as triangulation, prolonged engagement, peer debriefing, thick description and intercoder agreement, were used for assessing the accuracy of findings since each researcher is expected to assess the accuracy of their findings with the application of appropriate strategies and the reporting of them (Yıldırım \& Şimşek, 2013), they need to persuade the wider academic community that their findings are indeed trustworthy (Merriam, 2009). For triangulation, different data collection forms, different interviewee (students and teacher), and different data analyst were used. Prolonged engagement was met since the researcher participated in all sessions of each case as a facilitator throughout the implementation. The researcher actively sought out interaction with both the students and the teachers in each case for this purpose. Peer debriefing strategy was employed by the researcher via consulting colleagues of the researcher who was were familiar with the research process followed. Thick description was achieved by providing detailed information about the participants and each of the cases, and providing direct quotations of the participants while presenting the findings. For intercoder agreement, two intercoders analyzed some parts of the data in addition to the researcher. Firstly, the researcher explained the purpose of the current study, the research question, the data collection procedure and the overall research design of the study in a detailed way in order to inform the intercoders about the study. Then, the researcher analyzed one of the student interviews with each coder separately in order to inform them about the themes and sub-themes developed by the researcher. After that, each intercoder independently analyzed a different student interview. Lastly, the researcher and the intercoders discussed any differences and tried to form a consensus about them.

\subsection{Programming Environment: SDP}

SDP refers to Sanal Dünyada Programlama which means Programming in Virtual World. It was comprised of two components; 3D learning environment including a number of 
programming activities, and the Scratch for OpenSim (S4OS) program that is used for building code to complete activities in the $3 \mathrm{D}$ environment. Topics to be covered to teach basics of programming were specified by inspecting academic studies and educational textbooks prepared for teaching children programming. The activities were designed in OpenSim virtual world application based on an instructional theory, Goal Based Scenario (GBS).

\subsubsection{Scratch for OpenSim (S4OS)}

This program is used for creating code in the "Linden Scripting Language" (LSL), which is the original programming language of OpenSim. It is a modification of the original Scratch software that was modified by Rosenbaum (2008), a member of the MIT Lifelong Kindergarten team. In S4OS, users can build code by dragging and dropping known code blocks of the original Scratch program onto the 3D object being constructed. Unlike Scratch, S4OS does not produce any output of built code itself, but it is only used for creates LSL code based on the code blocks by the user. After building the code on this program, users then need to click the "Sanal Dünya Kodunu üret" (Generate Virtual World Code) button in order to translate the pseudocode of Scratch into LSL. After the translation process, learners attach the LSL code to an object or robots offered to them within the $3 \mathrm{D}$ environment in order to see the output of their code. Transferring code from S4OS to the virtual world is very easy and can be achieved simply through double-clicks by the user. Pellas (2014) argued that it could therefore be used easily by learners from primary school through to university level in order to create a wide range of $3 \mathrm{D}$ virtual artefacts in OpenSim.

The user language of the software's interface was English, but the researcher translated much of the interface into Turkish after obtaining the necessary permissions from the software's author. The S4OS interface is very similar to Scratch, except for stage and sprites. A screenshot of the S4OS programming environment is shown in Figure 1. As seen in Figure 1, the interface consists of four parts. There are eight code categories (top-left), with the relevant code blocks for each chosen category listed on the left. The area in the right-middle is used for dragging and dropping code blocks. Lastly, there is a button used for translating the code into LSL, labeled “Sanal Dünya Kodunu üret” (Generate Virtual World Code), and another button for translating the code from LSL to Scratch, labeled "kodu yapıştır" (paste code), which are both positioned at the top-right of the screen. 


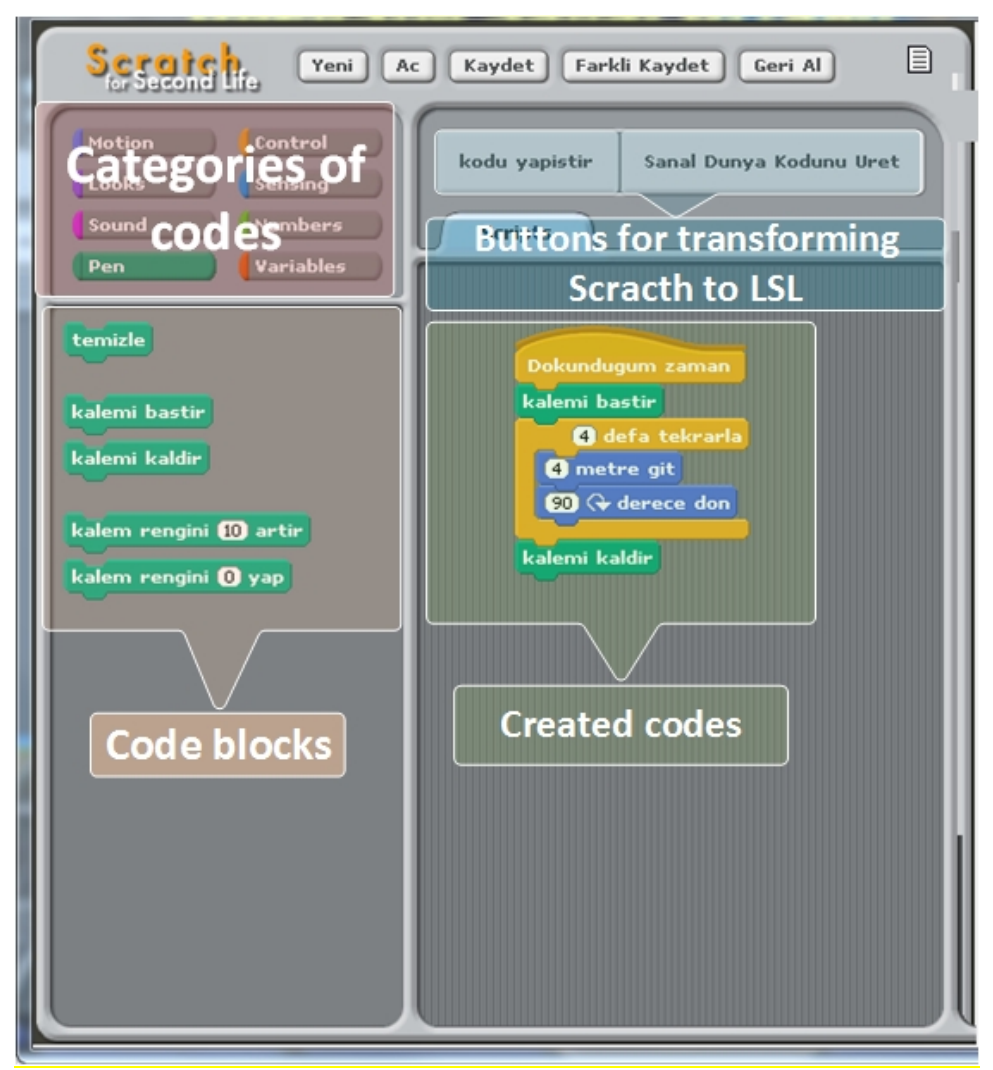

Figure 1. S4OS programming environment

\subsubsection{D Learning Environment}

A 3D virtual learning environment was designed and developed based on a platform called OpenSim since it allows developers to customize and develop their virtual worlds based on their specific needs. Participants used a 3D viewer for connecting, navigating, and building objects in a 3D virtual world. In this current study, the Imprudence viewer was used due to its extensive support available for LSL (Choudhury \& Banerjee, 2012), stability, and Turkish language support. Figure 2 shows a screenshot of the Imprudence viewer. Movement control, different forms of communication and customizing avatar appearance was possible via the components of viewer. 


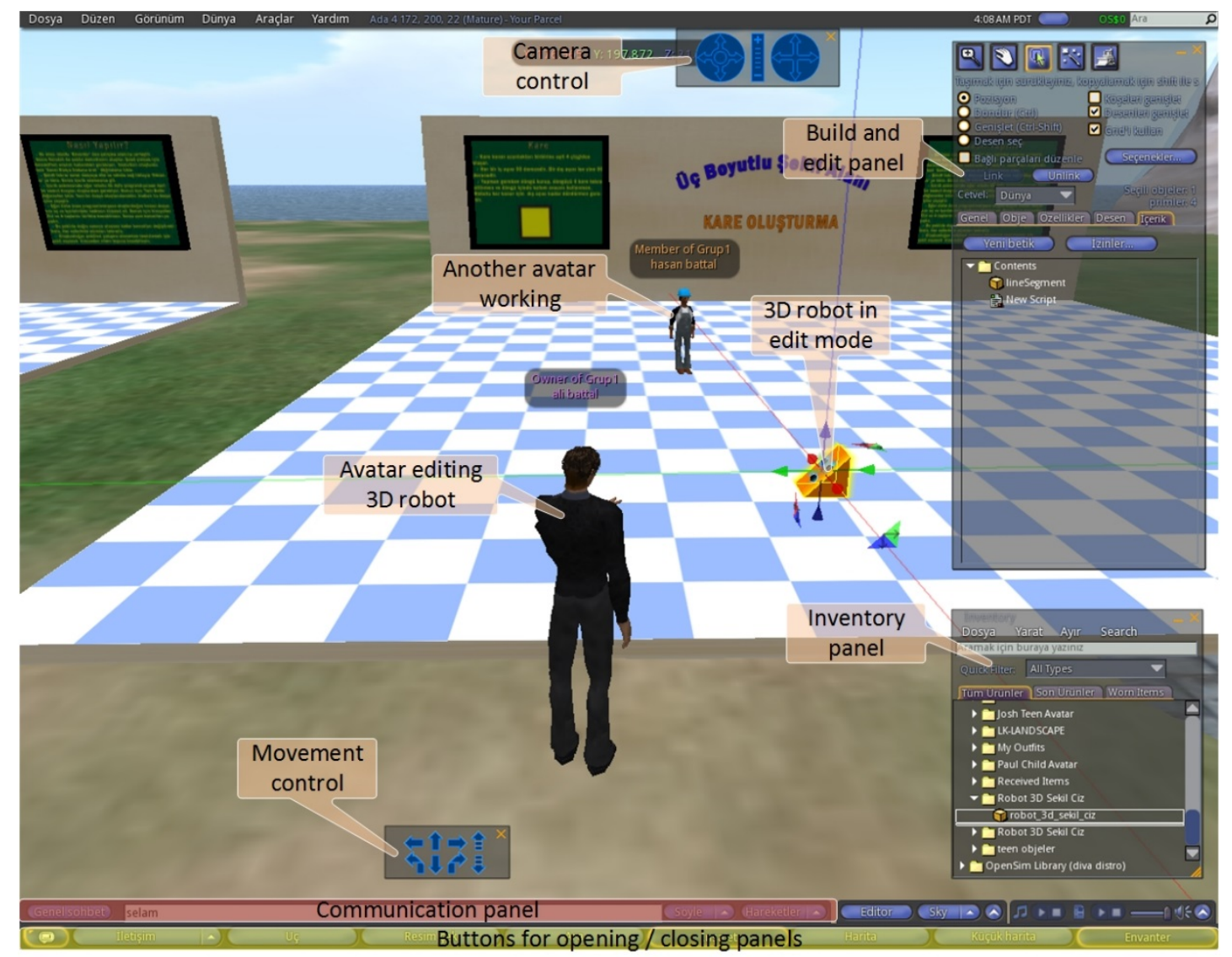

Figure 2. Screenshot of Imprudence viewer

The virtual learning environment was developed and built by the researcher in collaboration with experts. It was composed of two regions, named islands in OpenSim. The first island is for the orientation of students to the virtual world. The aim of this island is to introduce students to the generic skills of the VW including navigation within the environment, the creation of basic 3D robots and shapes, and the attachment of code required in order to keep them progressing on their chosen routes. The second is called "Sorunlu Kasaba," and was designed based on the theory of GBS. Students worked together on this island in pairs. There were a total of 24 tasks for each team and therefore each team member had 12 tasks to complete on the island. Each task was numbered from 1 to 12 and colored as either red or blue. A color was assigned to each student at the start of the study and they were tasked with completing all of the tasks with their corresponding assigned color. Each task was designed for the achievement of a specific learning goal.

The implementation phase of the study in each case consists of two parts taking place within two islands of 3D environment. The first part took place in the first island, which served as the 
orientation of students to the virtual world. Students were introduced how to use the generic VW skills including navigation within the environment, creation of basic 3D robots and shapes, and the attachment of code to the objects created. The second part of the study took place in the second island. Students completed 12 tasks in this part one by one along with their teammate.

\section{Results}

Satisfaction could affect students' approach to course in a positive or negative way. Participants' satisfaction level in the current study was measured via the application of a questionnaire. In addition, qualitative data were gathered via interview questions in order to determine the factors affecting student satisfaction. In this section, firstly, the status of satisfaction level is presented based on the descriptive analysis of the quantitative data, and the results are also supported with qualitative data. Then, the factors according to increasing and decreasing satisfaction of the participants are addressed, respectively.

\subsection{Current Status of Satisfaction}

The satisfaction questionnaire was adopted from Chou and Liu (2005), and consisted of four items. Descriptive results of the questionnaire are given in Table2. As can be seen, the students' scores were generally high for each item for Case-1. The total mean scores $(M=4.35)$ were moderately high. This could be interpreted as students having been generally satisfied from the study. The qualitative results supported the quantitative results. However, in this case, there were some factors of decreasing students' satisfaction scores from the outset of the study since students experienced some problems. Those problems were overcome during the second part of the study. One of the students commented about this, "I did not expect something like this, but I am satisfied at the end. However, I was not satisfied at the beginning."

The overall mean score of Case-2 $(M=3.99)$ was moderately high. Only two items relating to VW benefits learning achievement $(M=3.70)$ and satisfaction of overall learning effectiveness $(M=3.75)$ were lower when compared to the other two items. Qualitative results indicated that the expectation of most of the students were met by the end of the study, except for only two students argued the opposite in Case-2. For example, CS2-STUDENT5 argued that the study met his expectations more than he thought; because he thought he would learn programming in the club from a simple programming tool such as Lightbot; 
INTERVIEWER-So do you think this training met your expectations about programming?

CS2-STUDENT5- Yes but I wasn't expecting it to be like a virtual reality. INTERVIEWER-So you were expecting something simpler?

CS2-STUDENT5- Exactly. I thought they would be simpler things like Lightbot for example.

Table 2

Satisfaction questionnaire results

\begin{tabular}{lccccccc}
\hline & \multicolumn{3}{c}{ Case-1 } & \multicolumn{2}{c}{ Case-2 } & \multicolumn{2}{c}{ Case-3 } \\
\cline { 2 - 8 } & $M$ & $S D$ & $M$ & $S D$ & $M$ & $S D$ \\
\cline { 2 - 7 } & 4.33 & 0.78 & 4.40 & 0.68 & 4.38 & 0.74 \\
I was satisfied with SDP learning experience. & 4.17 & 1.19 & 3.70 & 0.80 & 4.38 & 0.92 \\
I think this SDP benefit my learning achievement. & 4.50 & 0.52 & 4.10 & 0.85 & 4.13 & 0.83 \\
I was satisfied with SDP. & 4.42 & 0.51 & 3.75 & 0.91 & 4.25 & 0.89 \\
I was satisfied with the overall learning effectiveness. & 4.35 & & 3.99 & & 4.28 & \\
Total & & & & & & \\
\end{tabular}

Descriptive results of the satisfaction questionnaire for Case-3 were similar to those of Case-1, and are presented in Table 2. As can be seen, the students ranked each item higher than four points. The overall mean $(M: 4.28)$ was quite high compared to Case-2. Moreover, the mean of each item was higher than four points. The qualitative results revealed from the interviews supported the descriptive results. Most of the students mentioned that the overall lesson met their expectation and that they enjoyed the study. CS3-STUDENT3 assumed that the lesson would similar to a traditional lesson in which PowerPoint presentations were used. On the contrary, she argued that it was more than what she had expected;

INTERVIEWER-And did this training meet your expectations?

CS3-STUDENT3- Yes, it did. It was even better than I'd expected. I thought we would do it after learning some more things from the presentations. I did not know there would be games or something like that.

\subsection{Factors increasing satisfaction}

Factors causing increase in students' satisfaction level were investigated through interview questions. Emerging factors based on the results were group study, object construction, tasks, off-task activities, 3D environment, story of tasks and touring in the 3D environment. The mostcited factor increasing the satisfaction of the students in Case-1 was group study. Most of the 
students $(n=6)$ argued that being together in groups and doing tasks together was a satisfying factor. Students really liked being a member of a group and to do the tasks together. CS1STUDENT2 commented on group study as, "Being together was the thing I liked the most." The other increasing factor stated by five of the students was regarding the tasks. Students mentioned that they liked the tasks that needed to be completed. Another factor was object construction, as stated by two students. The students liked to build 3D objects such as bridges, turtles, and walls of a shelter, and to code them. Other factors stated by one student were offtask activities, the 3D environment and tour of the environment. Students did not like to build objects related to tasks, but also they did like off-task activities. Moreover, traveling in the 3D environment as they wished was seen as a satisfying factor for one student.

The factors increasing the satisfaction of students in Case- 2 were similar to those of the first case. There was only one emerging factor that was different from the first case, which was about the story of tasks. The most-cited factor increasing the satisfaction of students in this case were object construction, 3D environment and off-task activities, which were each stated by six of the students. For example, CS2-STUDENT2 highlighted his greatest liked as, "It is possible to build and program what you want." Off-task activities and the 3D environment were the other emerging factors. Students liked to do extra things that were not related to the tasks they had been assigned in their free time. CS2-STUDENT2 and his teammate liked to resize the objects they constructed as an off-task activity in their free time after having finished their tasks and while waiting for the others to complete their own tasks;

CS2-STUDENT2- But when my teammate and I were waiting for others to finish after we were done with ours, we were creating more complicated stuff like houses with the things we used for other tasks, which we liked more.

Group study and tasks were the other emerging factors, with group study cited by five of the students, and tasks cited by four of the students. Similar to students in Case-1, students liked to be in a group and defined the group study as having been enjoyable. For example, CS2STUDENT2 defined this issue as studying in a group and being able to receive help were enjoyable and fun. Stories about each task was another emerging factor, which is different from Case-1. The teacher of Case- 2 and three of the students mentioned this factor. The students stated that stories about the tasks provided them with a mission, a reason to complete the tasks and the stories were creative, funny, and exciting. The teacher of this case also argued that the 
stories were helpful since they drew the students' attention to the tasks and it was a satisfying factor for the students to complete the tasks;

INTERVIEWER-And Madam, every task had a story. What do you think about those stories?

CS2-TEACHER- This is what we always do also in our lessons. I mean it definitely should have a story or a scenario and the kid should concentrate on that scenario so that s/he would feel enthusiastic while completing the tasks. I think it's satisfactory.

The last factor that emerged was touring in the 3D environment, which was mentioned by two of the students who liked to travel in the 3D environment by way of walking, flying, and driving cars.

Results showed that the emerging factors for Case- 3 were similar to those ones of Case-2, but with different frequencies. The major increasing factor in the satisfaction of the students $(n=6)$ was object construction. All of the students in this case mentioned this issue as a satisfying factor. CS3-STUDENT6 expressed her feeling as, "I most liked being able to build objects, which does not happen so fast in real life." The other most satisfied factor was group study, as stated by five of the students. In this case, the students liked being in a group as much as the students in the other cases. They expressed their feelings about group study as more enjoyable and fun. Off-task activities were the third major factor, which was stated by four of the students. In this case, the students liked to do off-task activities such as playing in the 3D environment with their friends, chatting in the breaks and so on; similar to the students of the other cases. The other factors were tasks, 3D environment and story of tasks, which were each stated by three students. The students stated that they liked the tasks and their stories as well as the 3D environment. For example, one of the students, CS3-STUDENT4, mentioned that the 3D environment was fascinating and had a well-planned story and that they all had a good rapport with each other. The last factor stated was touring the 3D world. Traveling by car was stated by one of the student as the most enjoyable;

CS3-STUDENT4- The story was well-matched with the island too. The island was planned very well, the story and everything were perfect. Actually the tasks, story and the island matched together very well. 


\subsection{Factors decreasing satisfaction}

Some factors revealed from the interview responses led to a decrease in the students' satisfaction. Those were technical problems, difficulty of task, avatar-related problems, difficulty of use and rearranging the code for the students of Case-1. Students studied alone in the first part of the study, and then studied alongside a teammate in the second part. Studying alone was the most-cited ( $n=3$ ) factor decreasing satisfaction of the students. Being alone was considered as boring and undesired for the students. For example, CS1-STUDENT2 expressed her feeling about studying alone as it being rather boring. Other decreasing factor was the technical problems encountered by two of the students. Technical problems were inevitable; however, they need to be limited to a minimal level. In this case, the students experienced some technical difficulties in the first part of the study due to poor computer hardware issues and weaknesses related to the infrastructure. One of the students highlighted that the technical problems he had faced decreased his satisfaction;

\section{INTERVIEWER- ... Did any difficulty you had with computer affect your satisfaction?}

CS1-STUDENT3- Sometimes I was upset because I couldn't. Because once, it just skipped... My computer was shut down and I couldn't complete the tasks. And I am also stressed out when it slows down. So all these affected my satisfaction badly.

Other factors were difficulty level of tasks and difficulty of use. Two students mentioned that difficulty of some tasks were above their level of capability. Difficulty of use was the other factor decreasing satisfaction. Of the total students, two claimed that it was difficult to use the programs and that this led to them to disliking the VW experience. The most problematic structure of the program was the inventory. CS1-STUDENT7 mentioned that she did not like to use the VW due to difficulty using its inventory and the complex structure;

INTERVIEWER-So was there anything that you didn't appreciate?

CS1-STUDENT7- The inventory was a bit complicated. It was difficult to move it from left to right. And I also failed at drag and dropping them [from inventory]. They were the difficulties that I faced.

Other factor was about the avatar that was stated by two of the students. It was not possible to move avatars when they became jammed in some parts of the 3D environment. Two students defined this situation as annoying. The last factor stated by one of the students was the need to rearrange code when they were wrong. CS1-STUDENT7 described this situation as frustrating; 
explaining that she tried to rebuild the code when she got it wrong, however, in this situation; she became bored and thought about just giving up;

CS1-STUDENT7-... Once you build the wrong code, you try to do it again but this time it gets boring, you think "Should I do it again, or not..."

The factors decreasing the satisfaction of the students in Case- 2 were quite similar to those in Case-1. A less than realistic environment and difficulty of use were the two most-cited factors decreasing satisfaction. Four of the students found the environment less than realistic and the graphics of the objects were defined as low. CS2-STUDENT5 commented on this issue as, "It seems that the $3 \mathrm{D}$ environment was less than realistic and the graphics of the $3 \mathrm{D}$ objects were low." Difficulty of use was cited by four of the students as another factor. The inventory and arranging the pop-up screen were stated as complex and also less liked. It was mentioned that it could be easier to use and thereby simpler to cope with. Being left to work alone in the 3D environment, technical problems encountered and the difficulty of the tasks were stated by three of the students as the least-liked. CS2-STUDENT3 mentioned about the difficulty of tasks; adding that he would be more satisfied if they could have been made easier. Technical problems encountered were considered as annoying situations for some of the students. CS2-STUDENT7 pointed to a technical problem as, "I did not like it when the computer froze." Issues related to the avatars such as getting jammed in the environment and not being able to change accessories were other factors stated by two of the students. Being alone was another factor that also decreased satisfaction. Students generally studied with their peers; however, they were alone in some situations. One of the students mentioned about studying alone as;

CS2-STUDENT6- As I said, it was boring when we were on our own, we couldn't do anything. Go there, put it, make this, turn it, and the task is over. But now that we have our friends, we go to the task, and do it together. I mean we help each other.

The results of Case-3 showed that technical problems, studying alone, a less than realistic 3D environment, the difficulty of the tasks and avatar-related problems were all factors decreasing the satisfaction of the students in this case. Technical problems were the most-cited, as mentioned by four of the students. For example, one of the students mentioned this as;

INTERVIEWER-And what was the thing that you did not like in this environment?

CS3-STUDENT3- [computer] froze once in a while, it was continuing on its own and it was not very good. 
The other factors were only stated by one of the student in this case. While one stated that being alone would be boring for him, another found the use of the VW hard. These were stated as annoying factors which caused them to be less satisfied. Moreover, one of the students compared the VW with the real world and commented that the VW was less than realistic. CS3STUDENT6 explained this issue with an example, arguing that although it was possible to understand the direction of a ball in the real world, it was not possible to realize this in the VW; adding that this was so frustrating for her;

CS3-STUDENT6- ...For example if I [had] a ball in real life, I would know where it would go. However [in virtual world] you have to change the direction of the ball all the time because you do not know the direction [that the ball would go to]. It really upset me.

\subsection{Cross-Case Analysis}

The students' satisfaction level was measured via a questionnaire in each of the three cases. The students' overall mean satisfaction scores for each case were just higher than four points. The descriptive results of the quantitative data show that the most satisfied students were from Case$1(M=4.35)$, Case-3 $(M=4.28)$ and Case-2 $(M=3.99)$, respectively. Students of Case-1 were not so satisfied in the first part of study due to the technical and infrastructural problems that they experienced. However, those problems were overcome in the second part of the study, which could be why their scores were higher than others in the end. It seems that the least satisfied students were those from Case-2. This might due to fact that they were in a more crowded class and it was impossible therefore for the teacher to deal with all the students to the same extent as the other cases. Moreover, some of them had high expectations from the club. Using VW in the club was unknown to the students before joining the club and it might therefore not have met their expectations as a whole. Students of Case-3 knew that the VW would be used to teach the basics of programming, having been informed and volunteered to take part in the course. This may explain why their satisfaction scores were above four points, almost to the level of the students of Case-1.

Increasing factors in the satisfaction of the students were determined in all three cases. Apart from the story about the tasks, other factors emerged across all three cases at different ratios (see Table3). Story of the tasks was not stated as an increasing factor by the participants of Case1. This may be due to the students in that case either disliking or having ignored the stories. The most satisfied factor stated by the students across all cases was group study. Building and 
programming objects together, off-task activities and the $3 \mathrm{D}$ environment were stated as the most satisfying factors for both Case-2 and Case-3, but they were not found so satisfying by the students of Case-1. However, Case-1 was applied as a more formal class exercise than the other cases. Due to timetabling problems in this case, students did not have so much free time to do off-task activities and explore the 3D environment on their own.

Table 3

Frequencies of Factors Increasing Satisfaction across the Cases

\begin{tabular}{lccccccc}
\hline & \multicolumn{2}{c}{ Case-1 } & \multicolumn{2}{c}{ Case-2 } & \multicolumn{2}{c}{ Case-3 } \\
\cline { 2 - 7 } & & $\boldsymbol{n}$ & $\boldsymbol{\%}$ & $\boldsymbol{n}$ & $\boldsymbol{\%}$ & $\boldsymbol{n}$ & $\boldsymbol{\%}$ \\
\cline { 2 - 8 } Group study & 6 & 86 & 5 & 50 & 5 & 83 \\
Object construction & 2 & 29 & 6 & 60 & 6 & 100 \\
Having tasks & 5 & 71 & 4 & 40 & 3 & 50 \\
Off-task activities & 1 & 14 & 6 & 60 & 4 & 67 \\
3D environment & 1 & 14 & 6 & 60 & 3 & 50 \\
Story of tasks & - & - & 3 & 30 & 3 & 50 \\
Tour in the 3D environment & 1 & 14 & 2 & 20 & 1 & 17 \\
\hline
\end{tabular}

As to the factors that decreased the students' satisfaction levels; technical problems, studying alone, difficulty of the tasks, and avatar-related problems were all factors stated by some of the students across all cases (see Table 4) that decreased their satisfaction. However, a less than realistic 3D environment was not found as a decreasing factor for the students from Case-1, but was found to be the most decreasing factor in Case-2 and less so in Case-3. This implies that while the students of Case-2 had a high expectation about the reality of the $3 \mathrm{D}$ environment, it appears that the students from Case-1 had no concerns about this issue. On the other hand, the students from Case-3 found the system easy to use and no student from this case not mentioned any difficulty of use as a decreasing factor.

Table 4

Frequencies of Factors Decreasing Satisfaction across the Cases

\begin{tabular}{lccccccc}
\hline & \multicolumn{2}{c}{ Case-1 } & \multicolumn{2}{c}{ Case-2 } & \multicolumn{2}{c}{ Case-3 } \\
\cline { 2 - 7 } & \multicolumn{2}{c}{$\boldsymbol{n}$} & $\boldsymbol{\%}$ & $\boldsymbol{n}$ & $\boldsymbol{\%}$ & $\boldsymbol{n}$ & $\boldsymbol{\%}$ \\
\cline { 2 - 8 } Technical problems & 2 & 29 & 3 & 30 & 4 & 67 \\
Studying alone & 3 & 43 & 3 & 30 & 1 & 17 \\
Difficulty of tasks & 2 & 29 & 3 & 30 & 1 & 17 \\
Avatar-related problems & 2 & 29 & 2 & 20 & 1 & 17 \\
Less than realistic environment & - & - & 4 & 40 & 1 & 17 \\
Difficulty of use & 2 & 29 & 4 & 40 & - & - \\
\hline
\end{tabular}




\section{Discussion}

Results of the students' satisfaction questionnaire across the three cases were almost all in excess of four points; with only the mean score in Case-2 slightly lower, but quite acceptable. One possible explanation for this might be that the class was more crowded and it was therefore more difficult for the teacher to deal with all the students. Another possible explanation might be that some of the students had high expectations from the club and using the VW might not have satisfied their expectations as a whole. Similar to this situation, the findings of Case-1 corroborate the second explanation because the students in Case-1 had low expectations from the current study and their satisfaction level was the highest. The overall results of each single case are consistent with previous studies, showing that the use of VW with its distinctive features has a positive effect on students' satisfaction in general (Hew \& Cheung, 2010), and in programming education (Buffum et al., 2015; Girvan et al., 2013; Hulsey et al., 2014; Pellas \& Kazanidis, 2014). Factors affecting the students' satisfaction are discussed in the following part. While designing VWs for programming education, these issues should be kept in mind.

\subsection{Factors increasing satisfaction}

Factors affecting students' satisfaction were revealed in the current study. Group study, object construction, tasks, their stories, off-task activities, the 3D environment and touring the environment were found as factors that increased the satisfaction level of the students. Group study and tasks were the most-cited in all three cases. Findings of the literature review are also in line with the findings of the current study. These results validate the findings of previous studies, arguing that having a partner and tasks that draw the attention of learners are factors associated with increasing the satisfaction of leaners (Bishop-Clark, Courte, \& Howard, 2006; Buffum et al., 2015; Crellin, Duke-Williams, Chandler, \& Collinson, 2009; Girvan et al., 2013; Rico, Martínez-Muñoz, Alaman, Camacho, \& Pulido, 2011).

There were no major differences among the factors except for the story of the tasks across the cases. The story of the tasks was not found as a factor in Case-1. Object construction, off-task activities, and the $3 \mathrm{D}$ environment were not mentioned as increasing factors by the students of Case- 1 as much as in the other two cases. Differences across the cases may therefore be due to timetabling issues associated with Case-1, where students did not have so much free time to do any off-task activities or explore the $3 \mathrm{D}$ environment at will. Results of the single cases are 
therefore in line with the literature review, showing that generic features of VWs such as the ability to move around freely (Hew \& Cheung, 2010), being able to create 3D objects and code them without difficulties (Girvan et al., 2013), and the existence of fun activities (Esteves, Fonseca, Morgado \& Martin, 2009) made the learning process enjoyable for the students. Additionally, "Working with peers on something meaningful is usually significantly more engaging and fun" (Berland, 2017, p. 140).

\subsection{Factors decreasing satisfaction}

Technical problems, studying alone, difficulty of tasks, and avatar-related problems were the least-liked factors stated by some students across all three cases and caused a decrease in the students' satisfaction. Previous studies found that technical problems were the biggest obstacle to student satisfaction in the use of VWs for educational purposes (Dawley \& Dede, 2014; Hew \& Cheung, 2010; Rosenbaum, 2008). The literature review shows that challenging tasks could lead students to Paper's (n.d.) "hard fun"; however, it might also lead them to frustration and getting stuck when the difficulty of tasks increased beyond their ability or comfort level (Brennan, 2013). The difficulty of tasks emerged as a factor that decreased satisfaction in the current study, which seems to be concerned with the latter argumentation of Brennan (2013). This finding suggests that there should be adequate support available for the students in order to prevent this situation from occurring.

Difficulty of use was also stated as a decreasing factor for student satisfaction. Some complex structures of the VW were mentioned in the first research question that could be the cause of this situation. Surprisingly, a less than realistic environment was not found as a factor decreasing satisfaction in Case-1, but it was found as the most decreasing factor in Case- 2 and less so in Case-3. This shows that while students of Case-2 had high expectation about the realism of the $3 \mathrm{D}$ environment, students of Case- 1 did not have any concerns about this issue.

\section{Conclusion and Recommendation}

VWs could be used as a programming environment for children. The multiuser nature of VWs, code visualization in 3D format, contextualization of what was learned in real life, and providing multifaceted feedback allow children to better understand the basics of programming. Findings showed the satisfaction level of children enrolling in each particular educational 
program and the factors affecting satisfaction. Those factors and issues should kept in mind while using VWs to teach programming for children. Similarities and differences among educational programs were revealed, which might be important for educators, school management and other stakeholders wanting to teach programming.

This study was conducted in a physical environment, with students participating in virtual learning activities within a computer laboratory. They interacted with each other in both the real world and the virtual world. Real world interaction could affect children's virtual world interaction. Therefore, similar studies could be conducted with participants physically separated by location to investigate the dynamics of the virtual environment. Multiple dedicated servers were used in the current study. However, only one dedicated server could be used by eliminating bandwidth and server problems. The OpenSim application was used in the current study as a VW application. Further research could be conducted with applications with different features to investigate their effects on programming education.

\section{Statements on ethics and conflict of interest}

The necessary permissions were granted from the Applied Ethics Research Center of the university with a document number " $28620816 / 341$ ” on 09.09 .2015 . Signed consent forms of both the parents and students were taken before starting to collect data. Ethical issues were considered throughout the study. There is no conflict of interest in this study. 


\section{References}

Beck, K. (2000). Extreme programming explained: embrace change. Retrieved from https://dl.acm.org/citation.cfm?id=318762

Berland, M. (2017). Constructionist Learning. In K. Peppler (Ed.), The SAGE Encyclopedia of Out-of-School Learning (Vol. 1, pp. 139-141). https://doi.org/10.4135/9781483385198.n59

Bishop-Clark, C., Courte, J., \& Howard, E. V. (2006). Programming in Pairs with Alice to Improve Confidence, Enjoyment, and Achievement. Journal of Educational Computing Research, 34(2), 213-228. https://doi.org/10.2190/CFKF-UGGC-JG1Q-7T40

Brennan, K. (2013). Best of Both Worlds: Issues of Structure and Agency in Computational Creation, in and Out of School. (Unpublished Doctoral Dissertation). Massachusetts Institute of Technology, Cambridge, MA.

Buffum, P. S., Frankosky, M., Boyer, K. E., Wiebe, E., Mott, B., \& Lester, J. (2015). Leveraging collaboration to improve gender equity in a game-based learning environment for middle school computer science. 2015 Research in Equity and Sustained Participation in Engineering, Computing, and Technology (RESPECT), 1-8. https://doi.org/10.1109/RESPECT.2015.7296496

Choudhury, J., \& Banerjee, I. (2012). Programming in Virtual Worlds for Educational Requirements: LSL Scripting and Environment Development Challenges. International Journal of Computer Science Research and Application, 2(3), 30-41.

Crellin, J., Duke-Williams, E., Chandler, J., \& Collinson, T. (2009). Virtual worlds in computing education. Computer Science Education, 19(4), 315-334. https://doi.org/10.1080/08993400903384950

Creswell, J. W. (2007). Qualitative inquiry and research design: Choosing among five approaches (2nd ed.). Thousand Oaks, CA: Sage Publications.

Creswell, J. W. (2012). Educational research: Planning, conducting, and evaluating quantitative and qualitative research. In Educational Research (4th ed., Vol. 4). https://doi.org/10.1017/CBO9781107415324.004 
Dalgarno, B., \& Lee, M. J. W. (2010). What are the learning affordances of 3-D virtual environments? British Journal of Educational Technology, 41(1), 10-32. https://doi.org/10.1111/j.1467-8535.2009.01038.x

Dawley, L., \& Dede, C. (2014). Situated Learning in Virtual Worlds and Immersive Simulations. In J. M. Spector, M. D. Merrill, J. Elen, \& M. J. Bishop (Eds.), Handbook of Research on Educational Communications and Technology (pp. 723-734). https://doi.org/10.1007/978-1-4614-3185-5_58

Delwiche, A. (2006). Massively multiplayer online games (MMOs) in the new media classroom. Educational Technology \& Society, 9(3), 160-172.

Dickey, M. D. (2005a). Brave new (interactive) worlds: A review of the design affordances and constraints of two 3D virtual worlds as interactive learning environments. Interactive Learning Environments, 13(1-2), 121-137. https://doi.org/10.1080/10494820500173714

Dickey, M. D. (2005b). Three-dimensional virtual worlds and distance learning: two case studies of Active Worlds as a medium for distance education. British Journal of Educational Technology, 36(3), 439-451.

Dieterle, E., \& Clarke, J. (2006). Multi-User Virtual Environments for Teaching and Learning. In M. Pagani (Ed.), Encyclopedia of Multimedia Technology and Networking (2nd Edition, Vol. 2, pp. 1033-1041). Retrieved from http://muve.gse.harvard.edu/rivercityproject

Dreher, C., Reiners, T., Dreher, N., \& Dreher, H. (2009). Virtual Worlds as a Context Suited for Information Systems Education: Discussion of Pedagogical Experience and Curriculum Design with Reference to Second Life. Journal of Information Systems Education, 20(2), 211-225.

Duncan, I., Miller, A., \& Jiang, S. (2012). A taxonomy of virtual worlds usage in education. British Journal of Educational Technology, 43(6), 949-964. https://doi.org/10.1111/j.1467-8535.2011.01263.x

Esteves, M., Fonseca, B., Morgado, L., \& Martins, P. (2009). Using Second Life for Problem Based Learning in Computer Science Programming. Journal of Virtual Worlds Research, 2(1), 23. https://doi.org/10.4101/jvwr.v2i1.419 
Girvan, C., Tangney, B., \& Savage, T. (2013). SLurtles: Supporting constructionist learning in Second Life. Computers \& Education, 61, 115-132. https://doi.org/10.1016/j.compedu.2012.08.005

Gomes, A., \& Mendes, A. J. N. (2007). Learning to program-difficulties and solutions. International Conference on Engineering Education, 1-5. Retrieved from http://ineer.org/Events/ICEE2007/papers/411.pdf

Guzdial, M. (2004). Programming Environments for Novices. In S. Fincher \& M. Petre (Eds.), Computer Science Education Research (pp. 127-154). Lisse, The Netherlands: Taylor \& Francis.

Hew, K. F., \& Cheung, W. S. (2010). Use of three-dimensional (3-D) immersive virtual worlds in K-12 and higher education settings: A review of the research. British Journal of Educational Technology, 41(1), 33-55. https://doi.org/10.1111/j.14678535.2008.00900.x

Hulsey, C., Pence, T. B., \& Hodges, L. F. (2014). Camp CyberGirls: Using a Virtual World to Introduce Computing Concepts to Middle School Girls. Proceedings of the 45th ACM Technical Symposium on Computer Science Education - SIGCSE '14, 331-336. https://doi.org/10.1145/2538862.2538881

Kafai, Y., \& Burke, Q. (2014). Connected code: why children need to learn programming. MIT Press.

Kelleher, C., \& Pausch, R. (2005). Lowering the Barriers to Programming: a survey of programming environments and languages for novice programmers. ACM Computing Surveys, 37(2), 83-137. https://doi.org/10.1145/1089733.1089734

Merriam, S. B. (1998). Qualitative research and case study applications in education. San Francisco, CA: Jossey-Bass Publishers.

Merriam, S. B. (2009). Qualitative research: A guide to design and implementation. San Francisco, CA: Jossey-Bass.

Messinger, P. R., Stroulia, E., Lyons, K., Bone, M., Niu, R. H., Smirnov, K., \& Perelgut, S. (2009). Virtual worlds - past, present, and future: New directions in social computing. Decision Support Systems, 47(3), 204-228. https://doi.org/10.1016/j.dss.2009.02.014

Miles, M. B., Huberman, A. M., \& Saldana, J. (2014). Qualitative data analysis: A methods sourcebook (3rd ed.). Thousand Oaks, CA: SAGE Publications. 
Neale, P., Thapa, S., \& Boyce, C. (2006). Preparing a case study: A guide for designing and conducting a case study for evaluation input. Pathfinder International Tool Series, (May), $1-12$.

Papert, S. (n.d.). Hard fun. Retrieved December 1, 2017, from http://www.papert.org/articles/HardFun.html

Patton, M. Q. (1990). Qualitative evaluation and research methods, 2nd ed. In Qualitative evaluation and research methods, 2nd ed. [BOOK]. Thousand Oaks, CA, US: Sage Publications, Inc.

Patton, M. Q. (2002). Qualitative research and evaluation methods (3rd ed.). Thousand Oaks, CA: Sage Publications.

Pellas, N. (2014). The development of a virtual learning platform for teaching concurrent program- ming languages in Secondary education: The use of Open Sim and Scratch4OS. Journal of E-Learning and Knowledge Society, 10(1), 129-143.

Pellas, N., \& Kazanidis, I. (2014). Online and hybrid university-level courses with the utilization of Second Life: Investigating the factors that predict student choice in Second Life supported online and hybrid university-level courses. Computers in Human Behavior, 40, 31-43. https://doi.org/10.1016/j.chb.2014.07.047

Pellas, N., \& Peroutseas, E. (2016). Gaming in Second Life via Scratch4SL:Engaging High School Students in Programming Courses. Journal of Educational Computing Research, 54(1), 108-143. https://doi.org/10.1177/0735633115612785

Pellas, N., \& Vosinakis, S. (2017). How can a simulation game support the development of computational problem- solving strategies? IEEE Global Engineering Education Conference (EDUCON 2017), (May). Athens: Greece.

Rico, M., Martínez-Muñoz, G., Alaman, X., Camacho, D., \& Pulido, E. (2011). A programming experience of high school students in a virtual world platform. International Journal of Engineering Education, 27(1), 1-9.

Rosenbaum, E. (2008). Scratch for Second Life. In S. V. Harrell (Ed.), Proceedings of the International Conference on Learning Sciences - ICLS 2008 (pp. 383-391). Retrieved from http://dl.acm.org/citation.cfm?id=1600042 
Sajjanhar, A., \& Faulkner, J. (2014). Exploring second life as a learning environment for computer programming. Creative Education, 5(1), 53-62. https://doi.org/10.4236/ce.2014.51010

Sauppé, A., Szafir, D., Huang, C.-M., \& Mutlu, B. (2015). From 9 to 90: Engaging Learners of All Ages. Proceedings of the 46th ACM Technical Symposium on Computer Science Education - SIGCSE '15, 575-580. https://doi.org/10.1145/2676723.2677248

Seng, K. L. J., \& Edirisinghe, E. M. N. S. (2007). Teaching computer science using Second Life as a learning environment. Ascilite, (14), 583-586.

Chou, S \& Liu, C. (2005). Learning Effectiveness in Web-Based Technology-Mediated Virtual Learning Environment. Proceedings of the 38th Annual Hawaii International Conference on System Sciences, 1-10. https://doi.org/10.1109/HICSS.2005.385

Stake, R. E. (2005). Qualitative Case Studies. In N. K. Denzin \& Y. S. Lincoln (Eds.), The SAGE handbook of qualitative research (3rd ed., Vol. 3rd, pp. 443-466). Retrieved from http://www.loc.gov/catdir/toc/ecip053/2004026085.html

Stake, R. E. (2006). Multiple Case Study Analysis. New York: The Guilford Press.

Woodside, A. G. (2010). Case study research: Theory, methods, practice. Bingley, UK: Emerald Group Publishing.

Yin, R. K. (1981). The case study crisis: Some answers. Administrative Science Quarterly, 26(1), 58-65. https://doi.org/10.2307/2392599

Yin, R. K. (2003). Case study research: Design and methods (Fourth Ed.). Thousand Oaks, CA: SAGE Publications.

Yıldırım, A., \& Şimşek, H. (2013). Sosyal bilimlerde nitel araştırma yöntemleri (9th ed.). Ankara: Seçkin Yayıncılık. 